\title{
2 Echoes of memories of forced displacement
}

\author{
The case of the Greek island of Lesvos
}

\author{
Marilena Anastasopoulou
}

\section{Introduction}

How do people's memories of forced relocation affect their identities, values, and attitudes towards contemporary migrants and refugees? In this chapter, I examine the potential effects of refugee memory through the historical parallel between the Greek-Turkish population exchange (1923) and the contemporary migration and refugee flows (2015). More specifically, while focusing on the case of the Greek island of Lesvos, the question that I aim to address is: how do people with family memories of forced relocation relate to contemporary migrants and refugees? To unpack the fluid relationship between history, memory, identity, and values, as well as the way they inform assistance to migrants and refugees, I will use evidence drawn from primary sources, including oral testimonies from my fieldwork on Lesvos in the course of 2017, and archival evidence.

Lesvos is an island that constitutes an entry port for significant contemporary migration flows and whose present population composition has to a large degree been formed by the 1923 population exchange. In Greece, the case of Lesvos is far from rare given that a significant percentage of the country's current population is descended from refugees from Asia Minor (Tata Arsel 2014). Manifold examples illustrate that a large percentage of Greece's population has experienced immigration and forced displacement. The reason I chose to examine forced displacement memories in Greece through the case study of the Greek-Turkish population exchange can be summarized in the following points. First, this exchange of populations poses paramount international interest in modern history since "[i]t was the first time in history that the transfer of large ethnic groups was tried as a means to separate nationally intermingled people' (Pentzopoulos 1962: 18). In addition, it is central to the Greek identity dominating 'the modern Greek consciousness as the fundamental event which has transformed the form and the character of the contemporary history of the nation' (Kitromilides 1972: 372).

Although limited in scope, the present chapter has broader implications and is relevant to many countries with similar traumatic experiences of forced displacement. Forced displacement has been experienced by a large 
percentage of people throughout the world. By drawing boundaries within intermingled populations through forced assimilation, large-scale human displacement, ethnic cleansing, and mass killings, nation-states were built on 'victories as much as on defeats, on "catastrophes" and traumas' (Akgonul 2009: 195), shaping collective memories central to ethnic identities.

Europe's current demographic profile is rooted in past relocation experiences of forced displacement. Considering this, the rise of xenophobic sentiment, the great debates with regard to refugees' distribution within the European Union, and the place of the newcomers in the host societies (Gero $\&$ Sik 2019; Main in this volume), it comes into question how and to what extent memories of forced migration influence people's attitudes towards contemporary migrants and refugees. My aim is to examine the effects of the wounds of memories of forced displacement on people's identities, values, and attitudes towards subsequent migration in the context of Europe's 'migration crisis.'

\section{Narratives}

The data that inform this chapter ${ }^{1}$ derive from the collection of primary sources using oral testimonies from my fieldwork on the island of Lesvos in 2017 and archival evidence from the Oral History Tradition archive of the Centre of Asia Minor Studies. ${ }^{2}$ It should be noted that this research is not designed 'to tell a fully representative story - an unmanageable task for any project that adopts in-depth interviewing' (Gildea \& Mark 2013: 11) but rather to unpack histories of subjectivities, providing a more diversified picture.

This chapter aims to shed light on the interplay between the Asia Minor refugee memory of forced displacement and people's identities and values with regard to subsequent migration in the context of Europe's 'migration crisis.' With this aim, the case of Lesvos has been chosen based on the following criteria. Firstly, this island experienced the greatest number of refugee arrivals in both 1923 and 2015 relative to its size and constitutes the largest port of arrivals and a traditional epicenter of both the past and the contemporary refugee arrivals. A second criterion is the island's proximity and exposure to the contemporary migration due to the existence of refugee camps and other accommodation facilities.

My main analytical category is Asia Minor refugees and their descendants of the second and third generations. My sample also includes people without refugee family background. Using snowball sampling and access to refugee associations, I traced people with refugee roots. I conducted 13 face-to-face, in-depth, and semi-structured interviews on the island of Lesvos in Mytilene (the capital and port of the island), Moria (a hotspot), and Kara Tepe (a refugee camp).

Through the lens of micro-history, I carried out an in-depth analysis at the individual level and related it to collective and cultural frameworks of 
remembrance. The questions of what kind of memory is transmitted and if it is lasting or changeable over time, as well as its imprint on the transmitted identities and values was elucidated through the conducted interviews. Tracing voices that otherwise would have been lost, my analysis went beyond traumatic events as such, examining histories of subjectivities and 'the changing uses and meanings of that past in the present' (Thomson 2015: 26).

\section{A historical parallel}

At the end of World War I, 'the logic of European nationalism as it tried to rationalize the end of a multi-confessional empire' (Mazower 1998: 61) underlined the events following the defeat of the Greek army in Asia Minor in 1922. Specifically, under the Lausanne Convention of January 30, 1923, Greece and Turkey agreed on the compulsory exchange of populations of their respective religious minorities: Greek Orthodox Turkish nationals living in Turkish territory and Muslim Greek nationals living in Greek territory. One of the paradoxes of using religion as a marker of identification was that a significant percentage of the Orthodox population was Turkish-speaking (Kitromilides 2011). The influx of refugees ${ }^{3}$ expelled from Turkey to Greece was estimated at around 1.2 million people, while the number of Muslims expelled to Turkey from Greece was approximately 360,000 (Ladas 1932). As a result, during a period of war (19121922) and economic deprivation, Greece increased its population by 25 percent. It should be noted that enormous numbers of refugees had fled Asia Minor before the population exchange, primarily escaping to the island of Lesvos (Doumanis 2012).

After World War II came other phases of migration and forced displacement to Greece. Most significant, however, was the fact that in 2015, Greece, a country faced with a political and economic crisis, once again experienced the arrival of vast numbers of displaced people. The unfolding forced migration of refugees and their concentration along the Eastern Mediterranean, and Western Balkan route has challenged not only frontline Member States, but also the European Union's asylum and border policy as a whole. According to the United Nations Refugee Agency, during 2015 and early 2016 more than one million migrants and refugees arrived in Greece (UNHCR 2018). Most of these people fled from violence and war in countries such as Syria, Afghanistan, Iraq, Pakistan, and Somalia and reached Greece by crossing from Turkey to the Aegean islands, such as the island of Lesvos (Triandafyllidou 2015). Specifically, on Lesvos, where 'over 45 percent of the 770,838 refugees and migrants who arrived in Europe in 2015 have landed' (UNHCR 2015), a 'new humanitarian geography' was developed (Papataxiarchis 2016a: 12). This new geography is comprised of the Moria hotspot (identification center), established in October 2015, becoming the first operational hotspot in Greece and existing alongside other refugee camps. 
This historical parallel can be seen, more vividly, in the light of the following testimonies in which two refugees describe their dangerous journey to Greece:

In the boats, we suffered many hardships. The heat, the dirty, the overcrowded boat... We were getting sick and many people were dying. We tied a stone to their neck and we threw them into the sea.

(Kallistheni Kallidou 1923, cited in Mourelos 2014: 259)

The moment we went on the inflatable boat, we felt something was wrong, it was losing pressure ... we decided to jump in the sea and hold on to the boat on both sides ... a wave hit me on my face and the water went inside my lungs, and I started to cough.... That's the moment I lost the boat.

(Mohamed 2015, cited in Amnesty International 2015: 2)

\section{A historical account of the Greek-Turkish population exchange}

The Greek-Turkish population exchange resulted in many demographic, ethnological, settlement, economic, political, social, and cultural effects, whose impacts form the central analytical theme of the largest body of the existing literature. Although the present analysis takes into account both Greek and Turkish historiography, in this chapter emphasis is given to the impacts of this exchange in Greece.

On both sides of the Aegean, the 1923 events led to nearly complete national homogeneity. Specifically, the effective settlement of refugees under the Refugee Commission had a profound impact on the ethnic homogenization and consolidation of Greece. The Asia Minor refugees became 'the frontier population' (Pentzopoulos 1962: 139), safeguarding the country's territorial integrity. Although it is known that the refugees brought new skills and expertise, there is a debate regarding their economic role. As far as the emerging political patterns are concerned, Mavrogordatos (1983) emphasizes the inherited legacy of the traumatic events in Greek politics, linking refugees' political behavior to the rise of the Communist Party. The political and primarily economic problems led to contested social relations between the newcomers and the local population, enhancing prejudice and hostility. The refugees on both sides of the Aegean were often stigmatized by local Turks as 'half infidels,' 'infidel seeds,' 'fake Muslims/Turks,' or 'Muslims of Ali Pasha of Ioannina,' and by local Greeks as 'Turkish seeds,' 'baptized in yogurt' or 'Orientals' (Hirschon 2003). The preservation of a separate identity, on the side of the newcomers, hindered their integration.

This conscious maintenance of a separate Asia Minor identity and cultural distinctiveness has been further illuminated by anthropological insights. Specifically, through her ethnography of Kokkinia, which is an urban quarter of the port city of Piraeus, Hirschon underlines that Asia Minor refugees would say, "referring to themselves, "We are Mikrasiates" (Asia Minor 
people)' (1989: 4). Salamone's (1987) rural study focuses on the refugee heritage and the reconstruction of the Asia Minor home of refugee islanders established in a Greek fishing village called Amuliani. Analyzing the two studies, Loizos wondered 'at what point do the subjects stop being explainable primarily as refugees' (1999: 245).

Although the Greek-Turkish population exchange has attracted a great deal of attention, few scholars have thus far analyzed if and how this refugee memory is related to contemporary attitudes towards migrants. This chapter will shift the focus to a micro-history and oral history approach in order to elucidate the formation of Asia Minor refugee memory in the context of Europe's 'migration crisis.'

\section{Asia Minor memories of the past and the refugee assistance in the present}

\section{Memory}

\section{Refugee memory}

There has been increasing interest among historians in the relationship between history and memory. Specifically, scholars distinguish between individual and collective frameworks of remembrance. One category of scholars, primarily comprised of cultural historians being influenced by sociologists, such as Halbwachs, develop the role of collective memory through reconstructing the past within a social context and considering individual memory insignificant (Halbwachs 1980; Nora \& Kritzman 1996). On the other hand, focusing on individual recollections, oral historians give authority to the interplay between individual and collective memory (Passerini 1979; Thompson 2017) and elucidate the relationship among individual, group, and national memories (Gildea 2010).

In my analysis, memory is conceptualized through the interplay between its various levels. On one level, it is seen as an embodied experience of Asia Minor refugees at the individual level that is mediated through familial, collective, cultural, and national frameworks of remembrance. The second level consists of collective memory shared by individuals within a group with shared memories, and the third level refers to cultural memory or the national narrative that concerns society as a whole (Gildea 2013). The interplay between the different levels of memory is elucidated from Lesvos' residents, who illustrate that the Asia Minor refugee memory pervades the island's narratives not only at an individual but also at a collective level. The role of refugee memory seems to exert a major influence on the way the community of Lesvos perceives, interprets, and ultimately acts on issues related to migrants.

There is collective memory on the island, and this space where we are now with the beach was the space that received many refugees from 
Turkey.... People have the memory of forced displacement, or the refugee memory, from the past generations.

(Manager of a municipal refugee camp, non-Asia Minor refugee descendant 2017)

\section{Memory of trauma and its intergenerational transmission}

'[T]rauma describes an overwhelming experience of sudden, or catastrophic events, in which the response to the event occurs in the often delayed, and uncontrolled repetitive occurrence' (Caruth 1991: 181). In my analysis, the question of whether subsequent migration triggers traumatic memories of forced displacement, is explored through the examination of the idea of a reawakened image of trauma (Druker 2011).

I do not want to talk about this [forced displacement] nor hear anything relevant, it was enough that we experienced it.

(Kuriaki Tsapa, first generation Asia Minor refugee, cited in Kitromilides 2016: 109)

We are reminded every time we see refugees landing on the island's shores of the scenes of exodus our mothers had described. We too were refugees.

(Asia Minor descendant of the second generation 2017)

The intergenerational transmission of these memories is elucidated by the structure of 'post memory,' which 'is a consequence of traumatic recall but $[\ldots]$ at a generational remove' (Hirsch 2008: 106). Given that 'trauma is both the event and the memory of the event' (Thomson 2015: 18), in the case of Lesvos the wound of forced displacement is transferred from the first to the following generations through family memories. Political scientists, as well as psychologists and anthropologists, stress that identities shaped in the context of a traumatic historical moment can have a longlasting and intergenerational effect. Hirschon, referring to the Asia Minor refugee memory, notes that 'its strength and persistence into the successive generations is impressive' (1989: 17).

This picture [of the violent forced displacement] after all these years neither faded nor could be deleted from my memory. I transferred it to my friends, and later to my wife, and my kids.

(Alexis Alexiou, first generation Asia Minor refugee, cited in Kitromilides 2016: 8)

Now that we are getting old, we tell stories about our lives to our children. (Vasilis Chatziathanasoglou, first generation Asia Minor refugee, cited in Mourelos 2004: 446) 
The first generation did not speak about its trauma. The second generation spoke even less and only with their families. The third generation, being integrated in Greece, speaks and organizes commemoration ceremonies and refugee associations.

(President of refugee association, Asia Minor descendant of the third generation 2017)

Sometimes this indirect transmission happens in an unconscious and nonlinear way. Specifically, Asia Minor refugees of the first generation were not always willing to share their stories for fear of evoking their pain or not being understood. In relation to the preservation of memory through family narratives, Gildea (2015) notes that people usually tell their life stories to their grandchildren towards the end of their lives. In the case of Lesvos, refugee memory is experienced indirectly and symbolically though oral history and is passed on from one generation to another.

\section{Identity and values}

The idea of belonging

Investigating the lingering effects of refugee memories and the way in which inherited identities influence people's values and ultimately their attitudes towards subsequent migrants and refugees, my analysis is based on the collective and individual identity of displacement. Identity as a sense of belonging cannot be limited to a specific ethnic context. Multiple forms of identity such as class, race, gender, and ethnicity intersect in societies and create different processes and practices of identification. The identity of Asia Minor refugees was formed through the coexistence of multiple layers of religious, educational, economical, and cultural particularities. However, it should be noted that decisions that do not result from people's free will often cause difficulties in the identification process. Hirschon states that refugees are 'by definition minority groups ... that are distinguished from others according to criteria which are used by them and by outsiders to define an identity different from that of the host society' (1992: 158). Kitromilides (2006) argues that refugees' identification was shaped by the hostility of the native population. Indeed, the often orientalist perspective of the native population lies at characterizations such as 'baptized in yogurt' that stigmatized refugees for years. This sense of a separate identity has been consciously maintained across generations through family memories.

They [the native Greeks] did not like us at all. They were saying: 'It would have been better if your boat sunk and you drowned in the sea! You eat our bread.'

(Ermolaos Andreadis, 1972, first generation Asia Minor refugee, cited in Kitromilides 2013: 95). 
Contested memories and contemporary attitudes

Tracing the ambiguous relationship between history, memory, and contemporary attitudes, the complex identities of the historically formed subjectivities of Asia Minor refugees are unpacked in the depth of the different contexts in which individuals made sense of their past. Following different approaches, scholars examine the role of individual and collective past as sources of formulation of the present with regard to attitudes towards outgroups. Examining the role of shared histories, Rothberg notes that '[i]t is often difficult to tell whether a given act of memory is more likely to produce competition or mutual understanding - sometimes both seem to happen simultaneously' (2009: 11).

The role of refugee memory came to light in every interview, revealing a nexus between an increased sentiment of sympathy towards contemporary refugees and the island's past refugee experience. This powerful memory constitutes what Papataxiarchis (2016b) defined as the Greek paradox. Rooted in the island's memories of forced displacement, the Greek paradox can be used in order to explain, for instance, the fact that despite the political flux, the economic austerity, and the vast migratory arrivals, the residents of Lesvos organized themselves to oppose and, ultimately, to close the office of the Greek far-right party, Golden Dawn, which was the main anti-immigrant force on the island. The emotional identification of Asia Minor descendants on Lesvos with the contemporary migrants and refugees has become apparent in numerous cases, bringing to light values of hospitality and empathy. For instance, as it has been pointed out by one of the interviewees:

In 2015, I went to the bakery and saw a couple being loaded onto a tractor with food, etc. and I asked: where are they being taken? They replied 'Every Saturday we do this in memory of our ancestors.' A lot of this happened in memory of people's parents and grandparents.

(Member of a local NGO, Asia Minor descendant of the third generation 2017)

Another example is Lesvos' grandmothers, whose mothers had arrived on the island by boats in 1922, who fed refugee infants. These and other examples have become symbols of solidarity. For instance, "in official discourse, the "three grannies [became] the image of the Europe that we want," the "good face of Europe"” (Papataxiarchis 2016c: 4). Through such actions, the values of hospitality, reciprocal support, and tolerance, which are rooted in Lesvos' past refugee experience, are enacted today.

The sensitivity that the island has demonstrated is greater than in all other areas of Europe ... We attribute this firstly to feelings of solidarity 
of the local community that has, to a large extent, refugee roots from the refugee flows from Asia Minor.

(Officer of the Chamber of Commerce, Asia Minor descendant of the third generation 2017)

The residents of Lesvos are more sensitive to such matters because a third of them are refugees of the third and fourth generation, including myself. We are more sensitive towards these migrants and refugees because we know the way the native population welcomed our ancestors.

(Municipal officer, Asia Minor descendant of the third generation 2017)

However, going beyond the idealization of the Lesvos case, it should be noted that the present chapter neither suggests that due to the island's refugee memory the notion of otherness is deterministically surpassed nor does it aim to establish a causal link between memory of forced displacement and contemporary attitudes. According to some of the interviewees, people tend to identify to a higher degree with Syrian refugees. The term 'refugee' in Greece goes back to the successful integration of the Asia Minor refugees and has a strongly positive connotation (Voutira 1991). In contrast, some of the interviewees use the word migrant inscribing a negative connotation to people who come from countries such as Afghanistan, Somalia, and Iraq.

We help the Syrians that they have war, the rest why are they coming? People who are coming from Africa are not refugees.

(Engineer of Moria hotspot, Asia Minor refugee descendant of the third generation 2017)

I think that there was a higher level of sympathy and tolerance towards the Syrians.

(Officer of the Hellenic Coast Guard, non-Asia Minor refugee descendant 2017)

We love and support the contemporary migrants and refugees but we cannot identify with them. We are not the same.

(President of refugee association, Asia Minor refugee descendant of the third generation 2017)

Examining theories of prejudice reduction of outgroup discrimination for the increase of empathy and reciprocal support (Loizos 1999) and theories of competitive victimization and hostility against outgroups (Vollhardt 2012), it becomes apparent that contested memories are shaped in the case of Lesvos, increasing empathy towards those who are perceived as refugees and hostility or competitive victimization towards those considered to be migrants. 


\section{Conclusion}

Do forced displacement experiences leave a lasting memory that is transmitted from one generation to the next and that influences identities, values, and ultimately attitudes towards contemporary migrants and refugees? Focusing on the case of Lesvos, I traced how descendants of refugees think about subsequent migration through the historical parallel between the Greek-Turkish population exchange and the contemporary migration and refugee flows.

The narrative of the Asia Minor refugee memory is not static and passive, but is instead actively reshaped and contested over time. In this chapter, memory is seen as a dynamic oscillation between continuities and discontinuities of the past and the present, through which historically formed subjectivities are unpacked in the context of Europe's contemporary 'migration crisis.' The way the subjectivities of Asia Minor refugees and their descendants are shaped across different generations, multiple levels - individual, collective, national - is elucidated through the fluid interplay between memory, storytelling, and contemporary attitudes. In this light, the nuanced relationship between memory, identity, and values, the conceptual tools of this study, and the extent to which they inform and construct each other, creating different practices of belonging over time and potentially producing empathy or hostility, are examined.

According to the presented results, transmitted from one generation to the next through family history, Asia Minor refugee memories change over time from reticent in the first generation with the direct traumatic experience, to latent in the second generation that was trying to get integrated into the host society, and to reawakened in the following generations that, being fully integrated and facing another shock, rediscover their roots. Tolerance and empathy are increased towards ethnic out-groups that are perceived as refugees, while on the other hand competitive victimization, and in some cases, hostility appear towards those considered to be migrants.

Overall, despite the island's vast migratory arrivals and the bruised economy, people's attitudes are characterized by feelings of compassion and understanding. These sympathetic attitudes derive from the phrase 'we too were refugees' and from the values of hospitality and tolerance, which have been inscribed not only in the descendants' memory but also in the island's collective memory. The existence of the values of hospitality and tolerance regarding the reception of subsequent refugees and the acceptance of histories of people with shared experiences is explained through the island's refugee memory, which is transmitted from one generation to another.

The importance of refugee memory as an experience at the individual level, a collective memory within a group with shared experiences, and a cultural memory that concerns society as a whole is paramount with regard 


\section{M. Anastasopoulou}

to the reception of subsequent migration and refugee flows. In Greece, a country that receives a high number of migratory inflows and whose present composition of population is rooted in past relocation experiences, the significance of these memories and the extent to which they inform identities, values, and attitudes is paramount.

\section{Notes}

1 The data come from two of my research projects entitled: 'Coming to term with forced migration: an intergenerational study of Asia Minor refugee memory' and 'Tracing the conflicting dynamics of policy implementation: The case of hotspots in Greece.'

2 Oral testimonies of the first generation, derived from the Oral History Tradition archive of the Centre of Asia Minor Studies in Athens, will be also examined. This archive comprises 5,000 oral testimonies of the first generation of refugees and is classified according to Asia Minor geographical settlements.

3 Technically the term 'refugee' does not apply to the people who were forcibly displaced under the Lausanne Convention because they were granted citizenship rights in the host countries. However, the 'terms people use to describe themselves are sociologically significant' (Hirschon 2003: xiii).

\section{References}

\section{Primary sources}

Asia Minor descendant of the second generation (2017). Interviewed by Marilena Anastasopoulou in Lesvos, March 2017.

Engineer of Moria hotspot, Asia Minor refugee descendant of the third generation (2017). Interviewed by Marilena Anastasopoulou in Lesvos, March 2017.

Manager of a municipal refugee camp, non-Asia Minor refugee descendant (2017). Interviewed by Marilena Anastasopoulou in Lesvos, March 2017.

Member of a local NGO, Asia Minor descendant of the third generation (2017). Interviewed by Marilena Anastasopoulou in Lesvos, March 2017.

Municipal officer, Asia Minor descendant of the third generation (2017). Interviewed by Marilena Anastasopoulou in Lesvos, March 2017.

Officer of the Chamber of Commerce, Asia Minor descendant of the third generation (2017). Interviewed by Marilena Anastasopoulou in Lesvos, March 2017.

Officer of the Hellenic Coast Guard, non-Asia Minor refugee descendant (2017). Interviewed by Marilena Anastasopoulou in Lesvos, March 2017.

President of refugee association, Asia Minor refugee descendant of the third generation (2017). Interviewed by Marilena Anastasopoulou in Lesvos, March 2017.

President of refugee association, descendant of the third generation of Asia Minor refugees (2017). March 2017.

\section{Printed primary sources}

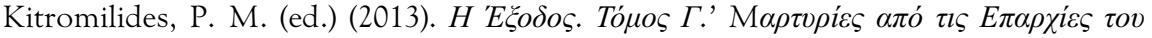

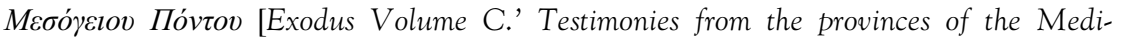
terranean Sea]. Greece, Athens: Centre for Asia Minor Studies. 


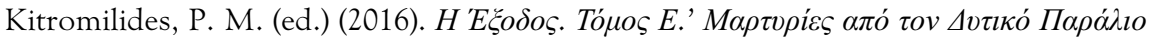

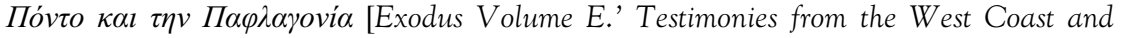
Paphlagonia]. Greece, Athens: Centre for Asia Minor Studies.

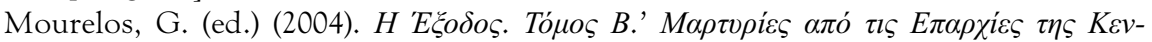

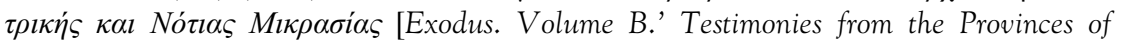
Central and South Asia Minor]. Greece, Athens: Centre for Asia Minor Studies.

\section{Printed secondary works}

Akgonul, S. (2009). 'Towards minority policies beyond reciprocity? The EU, Greece and Turkey,' in Anastasakis, O., Nicolaidis, K., \& Oktem, K. (eds), In the Long Shadow of Europe. Leiden, pp. 191-218.

Caruth, C. (1991). 'Unclaimed experience: Trauma and the possibility of history,' Yale French Studies 79(1), pp. 181-192.

Doumanis, N. (2012). Before the Nation. Oxford.

Druker, J. (2011). 'Trauma and latency in Primo Levi's The Reawakening,' in Sodi, R. \& Marcus, Millicent (eds), New Reflections on Primo Levi. New York, pp. 63-77.

Gildea, R. (2010). 'The long march of oral history: Around 1968 in France,' Oral History, 38(1), pp. 68-80.

Gildea, R. (2013). 'Utopia and conflict in the oral testimonies of French 1968 activists,' Memory Studies, 6(1), pp. 37-52.

Gildea, R. (2015). Fighters in the Shadows: A New History of the French Resistance. Cambridge, MA.

Gildea, R. \& Mark, J. (2013). 'Introduction,' in Gildea, R., Mark, J., \& Warring, A. (eds), Europe's 1968: Voices of Revolt. Oxford, pp. 1-18.

Halbwachs, M. (1980). The Collective Memory, 1st edn, New York.

Hirsch, M. (2008). 'The Generation of Postmemory,' Poetics Today, 29(1).

Hirschon, R. (1989). Heirs of the Greek Catastrophe, 1st edn, New York.

Hirschon, R. (1992). 'Memory and identity: The Asia Minor Greeks in Kokkinia,' in Papataxiarchis, E. (ed), Anthropology and the Past: Contributions to Social History in Modern Greece. Athens.

Hirschon, R. (2003). '“Unmixing peoples” in the Aegean Region,' in Hirschon R. (ed), Crossing the Aegean. New York.

Kitromilides, P. M. (1972). 'Contribution to the study of the Asia Minor tragedy: Evidence on the destruction of the Hellenism of Bithynia', Mikrasiatika Chronika, 15(1), pp. 372-398.

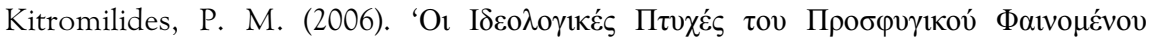

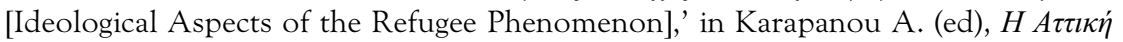

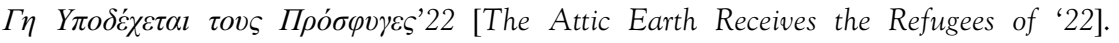
Athens, pp. 35-43.

Kitromilides, P. M. (2011). 'The end of empires, the Asia Minor catastrophe and the ecumenical patriarchy,' Bulletin of the Centre for Asia Minor Studies 17(1), pp. 29-42.

Ladas, S. P. (1932). The Exchange of Minorities: Bulgaria, Greece and Turkey. New York.

Loizos, P. (1999). 'Ottoman half-lives: Long-term perspectives on particular forced migrations,' Journal of Refugee Studies 12(3), pp. 237-263.

Mavrogordatos, G. T. (1983). Stillborn Republic: Social Coalitions and Party Strategies in Greece, 1922-1936. London. 


\section{M. Anastasopoulou}

Mazower, M. (1998). Dark Continent. London.

Nora, P. \& Kritzman, L. D. (1996). Realms of Memory: Rethinking the French Past, 1st edn, 1 vol. New York.

Papataxiarchis, E. (2016a). 'A great overturn: The "European refugee crisis" and the new patriotism of "solidarity”,' Contemporary Issues 132/133, pp. 7-28.

Papataxiarchis, E. (2016b). 'Unwrapping solidarity? Society reborn in austerity,' Social Anthropology, 24(2), pp. 205-210.

Papataxiarchis, E. (2016c). 'Being "there": At the front line of the "European refugee crisis", Anthropology Today 32(1), pp. 5-9.

Passerini, L. (1979). 'Work ideology and consensus under Italian fascism,' History Workshop Journal 8(1), pp. 82-108.

Pentzopoulos, D. (1962). The Balkan Exchange of Minorities and its Impact on Greece, 1 st edn. Paris.

Rothberg, M. (2009). Multidirectional Memory: Remembering the Holocaust in the Age of Decolonization. Stanford.

Salamone, S. D. (1987). In the Shadow of the Holy Mountain. New York.

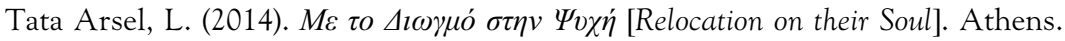

Thomson, A. (2015). 'Anzac memories revisited: Trauma, memory and oral history,' The Oral History Review 42(1), pp. 1-29.

Thompson, P. R. (2017). The Voice of the Past, 4th edn. Oxford.

Triandafyllidou, A. (2015). 'Turning the refugee crisis into an opportunity?: Current challenges for Greece and suggestions for action,' European University Institute 2015 (2), pp. 1-11.

Vollhardt, J. R. (2012). 'Collective victimization,' in Tropp, L. R. (ed), Oxford Handbook of Intergroup Conflict. Oxford, pp. 136-157.

Voutira, E. (1991). 'Pontic Greeks today: Migrants or refugees?' Journal of Refugee Studies 4(4), pp. 400-420.

\section{Websites}

Amnesty International (2015). 'Syria: voices in crisis,' November. Available at: www. amnesty.org/download/Documents/MDE2430252015ENGLISH.pdf

UNHCR (The UN Refugee Agency) (2018). 'Greece.' Available at: www.unhcr.org/ greece.html

UNHCR (The UN Refugee Agency) (2015). 'Lesvos Island - Greece,' UNHCR Factsheet, 12 November. Available at: www.unhcr.org/protection/operations/5645ddbc6/ greece-factsheet-lesvos-island.html 